International Journal of Linguistics, Literature and Translation

ISSN: 2617-0299 (Online); ISSN: 2708-0099 (Print)

DOI: $10.32996 / \mathrm{jjllt}$

Journal Homepage: www.al-kindipublisher.com/index.php/ijltt

\title{
The Image of Childhood in Pop Culture (Childhood in Crisis)
}

\section{Raluca Zbîrcea $\mathbf{8}$ (D)}

PhD Student, University of the West Timișoara, Faculty of Letters, History and Theology, PhD Studies Department; English and Italian Teacher at Jean Louis Calderon High School and Socrates High School Timișoara, Romania

$\checkmark$ Corresponding Author: Raluca Zbîrcea, E-mail: ralucazbircea@yahoo.com

ARTICLE INFORMATION ABSTRACT

Received: August 17, 2021

Accepted: September 19, 2021

Volume: 4

Issue: 9

DOI: $10.32996 / i j l t .2021 .4 .9 .20$

\section{KEYWORDS}

Childhood, crisis, gens, behaviour, nurture, pop-culture
This article will focus on the importance of educational values instilled in teenage characters of the Twentieth and Twenty-first century English and American Literature. Education is a fundamental part of intellectual freedom and one of its main values is enhancing how children view, exist in, and participate in the world (Rothwell, 2013). The scope of what follows is to examine the image of childhood in popular culture, comparing two great novels, Lord of the Flies by William Golding and The Hunger Games written by American novelist Suzanne Collins. In both novels, children tend to get into various crises, as evidenced by contrasting images. It is here where the survival instinct becomes dominant and children lose their childhood together with their innocence.

\section{Introduction}

To begin with, article's fundamental objective is to analyse childhood in crisis and to prove that in difficult circumstances, regardless of genetic background or education, the survival instinct becomes dominant and aggressive behaviour becomes the rule of law. The matter of how nature versus nurture influences human development has been an ongoing discussion for a very long time and, at present, the matter is up to debate, as both nature (genes) and nurture (environmental factors) seem to play a very important role in human development.

\section{Nature Versus Nurture}

Nature represents genetic inheritance and other biological factors also influence it. Nurture is mainly influenced by external or environmental factors that can have an impact on human development. As such, the purpose is not to question the power of heredity and the environment and as Haruki Murakami once wrote, "human beings are ultimately nothing but carriers passageways - for genes. They ride us into the ground like racehorses from generation. Genes don't think about what constitutes good or evil. They don't care whether we are happy or unhappy. We're just a means to an end for them. The only thing they think about is what is most efficient for them." (2016:1). Furthermore, Judith Rich states, "nature and nurture are the movers and shapers; they made us what are today and will determine what our children will be tomorrow." (2009:3) Essentially, it is the parent who determines the future of the child and the way they will raise their child will eventually determine what type of person they will turn out to be.

"The theme is an attempt to trace the defects of society back to the defects of human nature. The moral is that the shape of society must depend on the ethical nature of the individual and not on any political system however apparently logical or respectable" (William Golding)

The novel begins as it ends by emphasising how immature and childish young boys really are. Ralph, one of the main characters and maybe the only one who, by the end of the novel, still manages to restrain his "demons", is the oldest of them, however, there is something hopeless in his appearance: "he is dishevelled, with drooping stockings, as he picks his way through the forest to the lagoon, trailing behind him his school sweater" (Wilson, 1986:10). The author begins his novel presenting children's

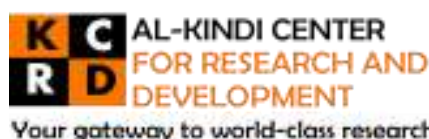

Your gateway to world-class research

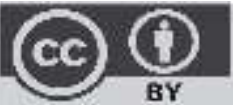

Published by Al-Kindi Center for Research and Development, London, United Kingdom. Copyright (c) the author(s). This open access article is distributed under a Creative Commons Attribution (CC-BY) 4.0 license 
emotions, thoughts and actions and while he does so, writing in such a precise manner, he manages to access their basic human nature. (Wilson, 1986:10)

Piggy, another lost boy on the unknown island, is the closest to the adult world. Despite his thick spectacles he cannot see very well, and constantly wants to be reassured that adult survivors must be among them. (Wilson, 1986:10) Essentially, his first question is: Where's the man with the megaphone? According to Raymond Wilson, when the boys realise that they are alone and no adult is among them or none has survived, "the contrast between Piggy's reaction and Ralph's delight at realising a boyish ambition to shake off adult authority is as pronounced as all the other differences, physical and social, between the two boys."(1986: 10) Furthermore, the conversation between the two boys doesn't give the reader full insight into how the boys ended up on the island, however it is clear that the author simply wants to plant the boys on the island his concern being "the creation of theologically significant experience rather than theological statement". (Bloom, 2010:55)

In Harold Bloom's opinion, William Golding describes

[...] realities of human behaviour and consciousness which theological statements indicate but do not enact. What is it like to experience the fall from innocence into sin? What is it like to experience damnation? To create an idolatrous god in the image of man or beast? To be stretched on the rack of such contraries as life and death, sacred and profane love, the self and the other? And, more tentatively, what would it be like to experience atonement and resurrection? These are some of the themes of Golding's novels, the stuff of existence upon which theological reflection operates." (2010:55)

Comparing the two novels, we come to the conclusion that the children portrayed in the Hunger Games novel are not falling from innocence into sin as the lost boys from Lord of the Flies, however they are born and raised as pawns for a corrupt society, the dystopian society of Panem. Here, the roles between adults and children are rather confusing and as Ahau Ming Tan writes, "as children are forced into adulthood by the mechanisms of the Games, we see adults conversely infantilised as adult disempowerment emerges as the result of its own childhood traumas." (2013:58) Moreover, children live in a world where adults rely on their children, destroying all their hopes and dreams, where they are born and raised as weapons and as the family's source of food.

The children of the districts can take tesserae, tokens that represent a year's worth of gain-"meagre year's supply of grain and oil for one person-"so that they can provide for the other members of the family."(Collins, 2008:15) By doing this, each time the suitable child must re-enter their name in the lottery of the Hunger Games, doubling the chances in being chosen as sacrificial tribute: "Childhood is stripped away as families and adults offer up their children as a potential sacrifice". (Susan Shau Ming Tan, 2013:56) In this dystopian society, where the children are used as a form of entertainment, the roles of the parents and the children are drastically changed especially because the parents constantly put their children in danger and by doing this, they lose the role of the protector "which should stand between the child and the Capitol". (Harvey, 2014:83)

"But here's the catch. Say you are poor and starving as we were. You can opt to add your name more times in exchange for tesserae. Each tessera is worth a meager year's supply of grain and oil for one person. You may do this for each of your family members as well. So, at the age of twelve, I had my name entered four times. Once, because I had to, and three times for tesserae for grain and oil for myself, Prim, and my mother. In fact, every year I have needed to do this. And the entries are cumulative. So now, at the age of sixteen, my name will be in the reaping twenty times." Katniss (Collins, 2008:14)

Ruchi Bhalla and Christopher Kowalski also address the idea of the survival of children and explain in their article about primitive defence mechanisms and societal discontent in Lord of the Flies. As such, once the group of boys find themselves abandoned on an island with limited resources and most of all with no adults, they begin to realise that their chances of survival are starting to fade and "surviving soon reverts to more primitive modes of functioning." (2007: 189)

"Without adult containment, the group disintegrates and regresses to the paranoid-schizoid position, held by Melanie Klein to be the earliest phase of psychic development. This position is dominated by persecutory anxieties and schizoid mechanisms, such as projection and the splitting of objects into either good or bad. At the same time, repressed id drives towards violence and death begin to surface, creating a dangerous mix of fear, anxiety, rage and lust for destruction."(Ruchi Bhalla and Christopher Kowalski, 2007:189)

Furthermore, as the construction of their society begins to disappear, they become more and more interested in dissolving the dangers that are hiding out in the wildness. As a group, they create the external object "the beastie" which they believe as being 
a hostile creature that needs to be eradicated at all costs. According to As Ruchi Bhalla and Christopher Kowalski the beast can be described as "both a projective identification of the boys 'anxieties about fear of extinction and an evacuation of the urges for violence and destruction that this anxiety has created". (2007:189) Finding themselves in this sort of situation and dealing with primitive defences born from unconscious fear and anxiety can manifest differently and may worsen at times of uncertainty. In this case, a group of well-educated schoolboys were stripped off from their civilised identity. Moreover, in times of anxiety and confusion, "it is not uncommon for groups to look for a collective enemy into which they can project and evacuate their anxieties as well as direct their growing feelings of anger and discontent". (Bahalla, Kowalski, 2007:189)

Both Lord of the Flies and Hunger Games could be novels about the evil of the human heart; however, as Harold Bloom points out it may be about "the frightening potential of children for violence."(2010:58) The intriguing fact is that both Collins and Golding manage to manipulate the reader in such an easy manner that we temporally forget that the characters of the novels are indeed children and not adults and by the end of the narrative, it all comes as a shock when realising that they are children after all and "we are willing to accept anything but this, even an atomic war, which now seems less savage than the violent obsessions of young Jack and his followers."(Bloom, 2010:59) Lord of the Flies ends in a rather sudden way while Ralph runs from the "savages with spears" only to be promptly saved by the arrival of a naval officer. This might represent the light at the end of the tunnel, the return to order and the holiness civilisation. (Lenz, 2012:1)

\section{A "Necessary" Evil}

What is interesting to notice is that while in Lord of the Flies salvation comes from an external source and it lays within the adult world, in The Hunger Games Susanne Collins demonstrates the impotence of the adult society by offering the salvation of Panem through the very same bow and arrow that Katniss used in her very first participation in the Games. Collins does this by employing the trope of the necessary evil (one must die so the others can live) by having Katniss aim her arrow at, and shoot point-blank, the new leader of Panem, who in her turn was also harbouring a dictatorial agenda. Continuing the idea of similarities between the two novels, it is worth considering the implications of education (nurture). Despite the poor education, the children from The Hunger Games are raised with the sole purpose of killing or be killed for the entertainment of the Capitol's inhabitants. However, these poorly educated youngsters are the ones who end up uprising against a completely real beast i.e. the dictatorial system of Panem.

On the other hand, considering their good education, the boys from Lord of the Flies end up creating "the beast"; a creature that is nothing more than a figment of the boys "imagination." (Shmoop Editorial Team) The young boys are afraid of things they hear and see during the night, rather than things they don't know. They create and give a name to the fear; however they cannot hunt and kill the imaginary "beast". In the end, the actual "something" does indeed appear: the dead parachuting man, who seems to come as a response to Ralph's plea for adult intervention. (Shmoop Editorial Team) Even more so, they start by wanting to kill an imaginary being purely in the scope of entertainment and continue by killing each other for the same entertaining reason.

William Golding commented on the ending of the story: "The officer, having interrupted a manhunt, prepares to take the children off the island in a cruiser which will presently be hunting its enemy in the same implacable way. And who will rescue the adult and his cruiser?"(Bloom, 2010:59)

The question of the uncertain way in which life will continue is also preeminent in The Hunger Games. While Golding finishes his novel using the implacable rescue ship, Collins ends the saga offering a brief moment of peace without addressing any of the implications that a post dictatorial Panem may carry. This is to say that while in both cases the reader may be relieved to find out that the protagonists escaped, a more inquisitive reader will determine that in spite of the character-centric success, the world of the characters will remain in disarray.

In a very pragmatic way one may try to understand the meaning of the word crisis by looking at the way in which this term has been defined by dictionaries and how it is used in today's world. When looking at the American- English (Merriam Webster) or British- English (Oxford dictionaries) linguistic approach to the word "crisis" one will come to notice a very strong resemblance in the way in which both dialects understand it. The consensus is that crisis represents:

"an unstable or crucial time or state of affairs in which a decisive change is impending; especially: one with the distinct possibility of a highly undesirable outcome, a time of intense difficulty or danger, a time when a difficult or important decision must be made." 


\section{Children in Crisis}

Taking from the above mentioned, this article will try to understand how the crisis appears, manifests itself, and is dealt with in both the Lord of the Flies and The Hunger Games. Both of the analysed plots use the theme of an unexpected critical event to establish and unfold the story. While in both, the crisis is a driving element at a closer look, one may distinguish between the completely unforeseen crisis (Lord of the Flies) and the unexpected crisis (The Hunger Games).

The idea of finding oneself isolated on a remote island after having survived the sinking of a passenger ship might constitute, and understandably so, a genuine reason of concern and hence a crisis situation. However, Golding does not waste much time in talking about the shipwreck proper as a crisis but disguises the aforementioned so that the reader may unravel the crisis behind the mask. It is here where we see that a group of surviving children are not much concerned with the sunken ship or how they got there, but their real reason of concern is found in establishing rank, asserting power, using and abusing the absence of adults and surviving; and herein lays the crisis. The world of Golden's novel is one under the constant pressure of impending doom. The surviving children are motivated to live not because they want to get home and reach their presumably worried families but because they want to kill an imaginary creature, one which supposedly threatens their very existence. This is the reason d'etre (catalyst) of the fake and imagined crisis. In their extensive attempts of trying to terminate the beast, the children only end up terminating precious time, precious resources and ultimately precious life.

It is also worth pointing out that when the children are faced with a possible voice of reason (Piggy) they collectively decide to dismiss the proper reasons of concern and maintain the ill-fated status quo. From a social point of view, this attitude can be understood since most communities, societies, and peoples have an adverse reaction and a predisposition towards resisting a status quo change. Unlike the crisis in The Hunger Games (which will be looked at in what follows), Golding's crisis is solvable only with adult intervention; this comes at a time when the notion of childhood and upbringing was completely different from those in society has today.

As stated in the introductory part of this paper, the crisis in Lord of the Flies was unforeseen as no one has expected a group of children to end up stranded on an island and then resort to horrendous acts of murder but in The Hunger Games the crisis comes unexpectedly as generations upon generations of children are breed and raised up knowing what they are expected to do once they reached the ripe age of eight. In the case of Katniss Everdeen, the main protagonist of The Hunger Games, the crisis comes unexpectedly as she needs to volunteer herself in order to save her sister from the certain slaughter she would have faced in the Arena.

"I volunteer!" I gasp. "I volunteer as tribute!"

There's some confusion on the stage. District 12 hasn't had a volunteer in decades and the protocol has become rusty. The rule is that once a tribute's name has been pulled from the ball, another eligible boy, if a boy's name has been read, or girl, if a girl's name has been read, can step forward to take his or her place. In some districts, in which winning the reaping is such a great honor, people are eager to risk their lives, the volunteering is complicated. But in District 12 , where the word tribute is pretty much synonymous with the word corpse, volunteers are all but extinct. (Collins,23)

At this stage, the crisis Katniss is facing is but a lead in towards while will turn out to be a continuous series of developments in which her initial crisis would develop to such an extent that from a singular person in Panem the crisis will engulf or encompass the entire nation resulting in revolution.

During her first time in the arena, Katniss finds herself dealing with the idea of children killing children. At first, she is averse to the thought of murdering other children but then, she soon realises that her own life is unsafe unless she starts taking others. This culminates with Katniss witnessing Rue being savagely killed; Rue being just a twelve-year-old little girl.

"When I break into the clearing, she's on the ground, hope lessly entangled in a net. She just has time to reach her hand through the mesh and say my name before the spear enters her body." (Collins,229)

"The boy from District 1 dies before he can pull out the spear. My arrow drives deeply into the center of his neck. He falls to his knees and halves the brief remainder of his life by yanking out the arrow and drowning in his own blood. I'm reloaded, shifting my aim from side to side, while I shout at Rue, "Are there more? Are there more?." (Collins, 230)

As soon as Katniss realises that she must play the game in order to get out alive, she faces the internal emotional process of accepting that it is either kill or be killed. As the progress of the event, and by the end of book one, we find our protagonist dealing with what seems to be a brief moment of calmness. She is then struck by the fact that she must re-enter the arena, but this time, she must kill experienced killers in their turn. Such as the progression of crisis upon crisis upon crisis that unfolds 
throughout the 3 books of the Hunger Games saga. Nevertheless, what seems to be an unchangeable, unavoidable and inescapable status quo ends up being dethroned by no other than poorly educated, malnourished and with no real adult role model children.

As mentioned previously, one might believe that the crisis in Golding's Lord of the Flies might have a solvable approach, while in Collins's Hunger Games the crisis has no solution whatsoever from the children's perspective. However, the result is surprisingly the opposite one. Instead of choosing the right way and listening to the voice of reason (Piggy and eventually Ralph) the boys choose the darker path. Not only do they kill the other boys but this desire to kill and hunt leads them to set on a fire and to destroy their community and what this has to offer. It seems unbelievable how the evil and the darkness had mastered their minds in such a way that by the end of the story, they manage to destroy fruit trees, their main source and along with this, as the animals run from the fire and the smoke, their other source that could ensure their survival. Therefore, until the man comes and rescues them, they seem to have lost almost their entire humanity, except for Ralph who is hiding and running from the other boys who have evolved into more expert hunters. Once an adult intervenes, to be more precise, the naval officer, everything changes, as the boys return to their normal emotional state, starting to cry and sob, leaving the roles of the savage hunters on the island and regaining the role of "little boys".

"Ralph looked at him dumbly. For a moment he had a fleeting picture of the strange glamour that had once invested the beaches. But the island was scorched up like dead wood- Simon was dead-and Jack had.... The tears began to flow and sobs shook him. He gave himself up to them now for the first time on the island; great, shuddering spasms of grief that seemed to wrench his whole body. His voice rose under the black smoke before the burning wreckage of the island; and infected by that emotion, the other little boys began to shake and sob too."(Golding, 1954, 225)

In the case of the children from The Hunger Games, as mentioned earlier, while reading the saga, the reader might have the feeling that in a dystopian dictatorial society where the Capitol seems to possess control over all twelve districts, a vision of a normal future or at least a considerable change in the society is rather hopeless and impossible. However, unlike the lost boys from Golding's Lord of the Flies, the children from The Hunger Games, eventually decide to form the rebellion against the Capitol and crush once and for all the cruel oppression that the government has instilled upon them and their families. As Katniss accepts the death of Rue, she becomes a symbol, accepting her desire to live, the desire for others to live, the desire for expression. (Susan Shau Ming Tan, 2013:58) Katniss wants to "do something...to show the Capitol that whatever they do...there is a part of every tribute they can't own" (Collins, Catching Fire, 286) In the end, Katniss accepts her power ": "the bird, the pin, the song, the berries, the watch, the cracker, the dress that burst into flames. I am the mockingjay....The symbol of the rebellion" (Collins, 466). This epiphany is revealed again as Katniss decides to join the rebellion:

"I take a deep breath. My arms rise slightly_as if recalling the black and white wings Cinna gave me-then come to rest at my sides. 'I'm going to be the Mockingjay'" (Collins, Mokingjay, 37)

The reader would have noticed that there are implicit references to violence and violation of innocence throughout both stories, and it is important to understand the source of this outcome. Does the survival instinct play an important part in justifying rather violent tendencies or is it simply human nature that drives people to simply choose a violent path towards aggressiveness, rebellion and, in the case of the shipwrecked boys, cannibalistic behaviour?

The answer is neither simple nor immediately apparent since, although in both stories, violence plays a prominent role Lord of the Flies lacks the social contexts in what upbringing is concerned which is to say that the protagonists should not have violent tendencies, while in The Hunger Games all children, regardless of their background are born and raised in a systematically oppressive and violent society.

When trying to connect the dots between violent predispositions and childhood, one may notice the profound paradoxical impossibility of such a connection ever existing. Namely, it would be fair to assume that children belonging to relatively wealthy families of the time would have benefited from a relatively high standard of education. Presumably, the protagonists of the Lord of the Flies would have had the above mentioned since we find them at the beginning of the book shipwrecked alone on an island. It stands to reason that such individuals come from an upper-tier background since not most families of that period would have had the means of sending their children on lavish or exotic maritime trips. This assumption is strongly validated at the end of the story when the surviving children meet with the naval officer who is in utter shock that proper British subjects have been capable of such abominable atrocities.

In contrast, one would expect to see children who have only heard about oppression and violence be exactly like that; oppressive and violent. In The Hunger Games this is not the case. The story presents a society of children who, in most cases, do not exhibit 
the need of killing much less the need of taking another's life with the sole purpose of being entertained. It is in the Hunger Games that we notice how upbringing (nurture) does not completely determine an individual's personality, we have Katniss, Rue, Peeta, Finnik et al., who participate in the Games because they are forced to do so, not because they saw a legitimate reason in doing so. The peculiarity here stems from the fact that a group of children who have had no civic education (unlike the protagonists of Lord of the Flies) and who have, their entire lives, been dedicated to simply surviving from one day to another have no desire to kill or to be violent when faced with a lifetime of resources and plenitude in exchange for killing twenty trees of their peers.

Since both books make heavy use of the theme of violence, it is worth taking into account where does this violence come from? Through a comparative lens the reader will see how in Lord of the Flies violence is purely internal, meaning the protagonists are violent because they want to be violent and are not forced to do so by other people or events, while in The Hunger Games violence is strictly external, i.e. the tributes become violent not because they want to be violent but because it is the only option when faced with their own demise.

One last comparison that is worth talking about is how characters from both books have their childhood violated and what results said violation might have on their lives. In Lord of the Flies the children, presumably, have had a life free of violence or tumultuous activities. However, this did not exempt them from undertaking a dark and violent life. While stranded on the island, the children found their innocence violated for the first time and in the wake of complete uncertainty, they have collectively and knowingly decided to become savage beasts and, at a later point, cannibalistic beings. Simply put, in Lord of the Flies the act of violating childhood happens only once but has, again, presumably irrevocable effects on the lives of the characters.

On the other hand, The Hunger Games presents to the reader from the very onset of the story a society that has complete disregard for innocent young lives and this way proceeds with systematically violating each individual's childhood. We see this from how children are raised in complete poverty to how they are refused the chance of a simple and happy life to the way in which they are selected taught and made into being killing machines for the pleasure of the rich. This is why in The Hunger Games the element of childhood violation appears systematically and rampantly affects all characters.

\section{You Can't Recover From Everything}

In both novels, the children experience traumatic events that have serious consequences on their continued life, while we can see the clear outcome of the traumatic events in The Hunger Games and, although we cannot dismiss the effects that said events had had on the children of The Lord of the Flies we can but assume what implications they may have had on the latter since the source texts end with the rescue of the children.

Reading Lord of the Flies one might presume that after all the events that happened on the island, the children might experience traumatic consequences, especially emotional ones. Even though the writer doesn't give specific arguments in what happens after the naval officer rescues the boys, and the story ends with the boys, fewer than they were at the begging of the story, the effects of the trauma they have exposed themselves to, i.e. killing Piggy, savagely murdering Simon, destroying their only source of survival (the island) and the shelters that Ralph deliberately assembled and in the end viciously hunting Ralph, become powerfully noticeable as soon as the presence of an adult male joins them on the island.

"We saw your smoke. And you don`t know how many of you are there?

'No sir. [...] We were together then-'[...]

And in the middle of them, with filthy body, matted hair, and unwiped nose, Ralph wept for the end of innocence, the darkness of man's heart, and the fall through the air of the true, wise friend called Piggy."(Golding, 1954, 225)

As opposed to reading Hunger Games, where the traumatic experiences dominate the entirety of the story, the characters are subjects of a controlling and dictatorial government that exposes its children to acts of scarring violence. These acts and their traumatic effects are apparent from the early onset of the book and continue with even more power until the very end of the saga, i.e. initially, the trauma takes the form of starvation, harsh conditions, which can be equated to physical trauma.

As things progress, we begin to understand that the dimension of trauma that children experience evolves from a purely physical one to a very diabolical, physical and emotional trauma: dealing with gathering sponsors ("you really want to know how to stay alive? You get people to like you"... Just remember, Katniss, you want the audience to like you." (The Hunger Games, 2012: 115)), doing gruesome acts of violence in order to get sponsors in the arena, the feeling of guilt while thousands of people are murdered in the revolution (survivor's guilt). Katniss sees herself as a survivor, comparing herself with the other poor people who have died in the revolution that she started, especially her sister Prim, who was collateral damage. Furthermore, due to exposing innocent children to gruesome acts of violence and having experienced such traumatic situations, which no child should ever come upon, it is easy to presume that these children will suffer a great deal of post-traumatic stress in the future. 
Reading and studying the books, we come to the conclusion that even though a lot of violence and loss of innocence is portrayed throughout the stories that one might wonder if there is still hope for the characters; will some of them at least overcome the human condition, regardless their education, social and moral values? "Children are lost, and voices are silenced and as Katniss fights against dictates of society that demand this sacrifice she becomes the 'girl on fire', fighting against impotency of the burning child's cry, demanding that the adult world take notice" (Shau Ming Tan, 2013:55)

\section{Conclusions}

Throughout this article, we have looked at how violence plays a key role in both stories, the only difference being that while violence in Lord of the Flies is shown as a point of no return in the personality of the children in The Hunger Games, violence is but an external factor that may seem impossible to overcome for the main characters yet through a very painful journey Katniss and all the others evolved manage to overcome the limits imposed by the Capitol and pave the way to a better Panem and in doing so offer generations to come a chance of living their childhood they never had which is a childhood free of death, sacrifice and the Hunger Games. We have seen that while in both novels, the characters make use of violence and in doing so they lose their childhood innocence, in Lord of the Flies, violence is not used as a way of survival by the characters since it is used as a way of passing the time. In The Hunger Games, the main characters only use violence as a last resort when they see that no other option could guarantee their survival. One may say that when Collins' characters use violence, they have lost their childhood purity, but on the other hand, they have gained what the Capitol wanted to take away from them from the beginning, the right to live. Interesting niche research could be done on how pop culture role models influence or justify the violent outbursts of today's youths, and if said outbursts have always been a characteristic of the young? In doing so, the research would determine if character/trait aspects are something that we've always had (which would stand if we were to look at the character of the fictional characters in this article) or if these aspects are something of a novelty that has crept into the common conscience as of late?

\section{References}

[1] Golding, W. (1954). Lord of the Flies. London: Faber and Faber Limited.

[2] Collins, S. Catching Fire. (2009). London: Scholastic.

[3] Collins, S. (2008). The Hunger Games. London: Scholastic,

[4] Collins, S. (2010). Mockingjay. London: Scholastic,

[5] Kristen L. (17 July 2012). What comparison is implied at the end of the novel Lord of the Flies?.

[6] McCrum, R. (16 Feb. 2015). The100 Best Novels: No 74 - Lord of the Flies by William Golding The Guardian, Guardian News and Media. Retrieved from www.theguardian.com/books/2015/feb/16/lord-of-the-flies-100-greatest-novels-william-golding-mccrum.

[7] Shmoop Editorial Team. (11 Nov. 2008). The Beast in Lord of the Flies. Shmoop University, Inc.

[8] Shau Ming Tan S. (January 2013). Burn with Us: Sacrificing Childhood in The Hunger Games. The Johns Hopkins University Press, Volume 37, Number 1.

[9] Harvey, S. (August 2014). No Child Left Unharmed: The Image of the Child in The Hunger Games. Journal at the University of Northern Colorado, 4(2).

[10] Bloom, H. (2010). Bloom`s Guides William Golding`s Lord of the Flies, Bloom`s Literary Criticism. Infobase Publishing.

[11] Wilson, R. (1986). Lord of the Flies by William Golding, Macmilan Master Guides. Macmilan Education LTD.

[12] Bhalla R. and Kowalski C. (2017). What Lord of the Flies teaches us about primitive defence mechanisms and societal discontent. The British Journal of Psychiatry. Retrieved from: www.theguardian.com/books/2015/feb/16/lord-of-the-flies-100-greatest-novels-william-goldingmccrum.

[13] Crisis.(1999). Merriam-Webster's Collegiate Dictionary . Merriam-Webster Incorporated. Retrieved from: www.merriamwebster.com/dictionary/crisis.

[14] Crisis. (1996). Oxford. Oxford Dictionaries. Retrieved from: en.oxforddictionaries.com/definition/crisis. 